\title{
ДИНАМІКА ЗМІН РОЗРАХУНКОВИХ ПОКАЗНИКІВ ЛАЗЕРНӦ̈ ДОПЛЕРІВСЬКОЇ ФЛОУМЕТРІЇ ОПІКОВИХ ПОВЕРХОНЬ У ХВОРИХ 3 ТЕРМІЧНОЮ ТРАВМОЮ ПРИ ПРОВЕДЕННІ РАННЬОГО ХІРУРГІЧНОГО ЛІКУВАННЯ З ВИКОРИСТАННЯМ ГІДРОГЕЛЕВИХ ПОВ'ЯЗОК ТА ПІНОПОЛІУРЕТАНОВИХ АДСОРБЕНТІВ
}

А. О. Ковальчук

ДВНЗ «Тернопільський державний медичний університет імені І. Я. Горбачевського МОЗ України»

Досліджено динаміку змін показників амплітудно-частотного спектра та середньоарифметичних значень показників мікрогемоциркуляції опікових ран у хворих з термічною травмою при проведенні ранньої некректомії 3 подальшим закритям ран сітчастими гідрогелевими засобами та губчастими адсорбентами. Виявлено, що нормалізація показників лазерної доплерівської флоуметрії відбуваеться статистично достовірно швидше на ділянках опікового ураження дерми, на яких використовували з метою лікування комбіновані гідрогелеві покриття та пінополіуретанові сорбуючі губки, порівняно з групами спостережень, у яких з метою місцевого лікування використовували антисептики та гідрогелеві монопокриття.

Ключові слова: опіки, лазерна доплерівська флоуметрія, мікроциркуляція, гідрогелеві покриття.

\section{ДИНАМИКА ИЗМЕНЕНИЙ РАСЧЕТНЫХ ПОКАЗАТЕЛЕЙ ЛАЗЕРНОЙ ДОППЛЕРОВСКОЙ ФЛОУМЕТРИИ ОЖОГОВЫХ ПОВЕРХНОСТЕЙ У БОЛЬНЫХ С ТЕРМИЧЕСКОЙ ТРАВМОЙ ПРИ ПРОВЕДЕНИИ РАННЕГО ХИРУРГИЧЕСКОГО ЛЕЧЕНИЯ С ИСПОЛЬЗОВАНИЕМ ГИДРОГЕЛЕВЫХ ПОВЯЗОК И ПЕНОПОЛИУРЕТАНОВЫХ АДСОРБЕНТОВ}

А. А. Ковальчук

ГВУЗ «Тернопольский государственный медицинский университет имени И. Я. Горбачевского МЗ Украины»

\begin{abstract}
Исследована динамика изменений показателей амплитудно-частотного спектра и среднеарифметических значений показателей микрогемоциркуляции ожоговых ран у больных с термической травмой при проведении ранней некрэктомии с последующим закрытием ран сетчатыми гидрогелевыми средствами и губчатыми адсорбентами. Выявлено, что нормализация показателей лазерной допплеровской флоуметрии происходит статистически достоверно быстрее на участках ожогового поражения дермы, на которых использовались с целью лечения комбинированные гидрогелевые покрытия и пенополиуретановые сорбирующие губки, по сравнению с группами наблюдений, в которых использовались с целью местного лечения антисептики и гидрогелевые монопокрытия.
\end{abstract}

Ключевые слова: ожоги, лазерная допплеровская флоуметрия, микроциркуляция, гидрогелевые покрытия.

\section{DYNAMICS OF CALCULATED VALUES OF LASER DOPPLER FLOWMETER OF BURN SURFACE IN PATIENTS WITH THERMAL INJURY IN CONDUCTING EARLY SURGICAL TREATMENT USING AND POLYURETHANE HYDROGEL BANDAGES ADSORBENT}

A. O. Kovalchuk

SHEI «Ternopil State Medical University by I. Ya. Horbachevsky of MPH of Ukraine»

The dynamics of changes of amplitude-frequency range and medium-arithmetic values of the microcirculation hemo burn

(C) А. О. Ковальчук 
sponged adsorbents. Revealed that normalization of laser Doppler flowmeter is statistically significantly faster in areas of burn lesions of the dermis where used in the treatment of combined hydrogel coatings and polyurethane sponge sorbing groups compared with observations, which were used in order to treat local antiseptics and hydrogel mono coverage.

Key words: care, laser Doppler flowmeter, microcirculation, hydro gel coating.

Вступ.Клінічна діагностика глибини опіків на практиці багато в чому залишається суб'єктивною. Зазвичай площу і глибину термічного ураження встановлюють в ході лікування на підставі динаміки ранового процесу після демаркації некрозу [1].

На сьогоднішній день для об'єктивізації клінічної діагностики глибини і площі опіків пропонується ряд методик [2, 3]. Ці методики грунтуються на використанні різноманітних фізичних феноменів, які дозволяють виявити зміни в уражених тканинах.

Для вивчення стану мікрогемоциркуляції в 1980 році було запропоновано метод лазерної доплерівської флоуметрії (ЛДФ). У його основі лежить зміна довжини хвилі лазерного випромінювання, що виникає при зондуванні рухомих еритроцитів лазерним променем.

При ЛДФ сигнал реєструється від об'єму тканини порядку одного кубічного міліметра. У такому обсязі тканини міститься близько 200 мікросудин і одноразово знаходиться близько трьохсот п'ятдесяти тисяч еритроцитів, тому ЛДФ-сигнал, що характеризує перфузію тканин кров'ю, відображає сукупність процесів, які одномоментно перебігають у всіх мікросудинах, що знаходяться в зоні вимірювання. Ритмічні коливання кровотоку та їх зміни дозволяють отримувати інформацію про співвідношеннях механізмів, що визначають стан мікрогемоциркуляції $[4,5,6]$. У сучасних апаратах вихідна інформація вводиться в комп'ютер, де відбуваються ії візуалізація та математична обробка. До розрахункових показників ЛДФсигналу належать такі показники, як середнє арифметичне значення показника мікрогемоциркуляції, середньоквадратичне відхилення і коефіцієнт варіації, а також показники амплітудно-частотного спектра [7]. Зміна потоку крові в системі мікроциркуляції за одиницю часу (Мл / хв на 100 г тканини) виражається в перфузійних одиницих (ПФ ОД). ЛДФ дозволяє проводити одномоментне або динамічне неінвазивне визначення капілярного кровотоку в поверхневих шарах шкіри [8-11].

Нами обрано цей метод, як один з найточніших та найінформативніших, 3 метою оцінки порушень та динаміки відновлення кровопостачання у зоні термічного ураження.

Мета роботи: дослідити особливості гемодинаміки ран у хворих з опіковою травмою за умови про- ведення раннього хірургічного лікування з використанням гідрогелевих пов'язок та пінополіуретанових адсорбентів.

Матеріал і методи дослідження. Нами проведено порівняльний аналіз показників гемодинаміки ран у обпечених хворих трьох клінічних груп. Індекс тяжкості ураження (індекс Франка) у пацієнтів всіх клінічних груп не перевищував 60 ОД.

І групу клінічних спостережень склали 29 хворих. Лікування пацієнтів проводили за класичною схемою: відтермінована некректомія, яка виконувалась 3 6-7 доби після отримання травми. Підготовка ран до аутодермопластики здійснювалася з використанням волого-висихаючих пов' язок з антисептиками (бетадин, діоксидин, хлоргексидин, декасан). Надалі проводилась аутодермопластика ран аутоклаптями шкіри товщиною $0,25-0,3$ мм.

До складу П групи увійшло 34 хворих. На відміну від першої групи, в цих пацієнтів проводилася рання некректомія на 2-3 добу від моменту отримання травми, та підготовка ран до аутодермопластики 3 використанням гідрогелевих монопов'язок. Пластика ран здійснювалася аутоклаптями шाкіри товщциною 0,25-0,3 мм.

До ІІІ групи увійшов 71 хворий. У даній групі проводилась рання некректомія на 2-3 добу після отримання термічної травми. Надалі місцеве лікування здійснювали з використанням сітчастих гідрогелевих пов'язок та губчастих сорбуючих засобів. Перев'язки проводились 1 раз на 48 годин. Готовність рани до аутодермопластики підвтерджувалася наявністю рожевої грануляційної тканини з ознаками капілярної кровотечі та нормалізацією показників за даними ЛДФ.

ЛДФ-метрію в ділянці опікових поверхонь проводили за наступною методикою: спочатку видаляли пов'язки і відшарований епідерміс, якщо такий залишився, надалі проводили туалет рани, виконували клінічну оцінку стану рани. Потім датчик прилада після попередньої обробки антисептиком АХД 200 підводили до обраної для обстеження ділянки опікової рани, не чинячи на нього тиску. За допомогою миші комп'ютера включали запис ЛДФ-грами і здійснювали ії запис впродовж 30-40 секунд. У ході запису активної ЛДФ-грами проводили іï візуальну оцінку. Після закінчення запису оцінювали отримані 
значення показника мікроциркуляції. Далі датчик переставляли на наступну ділянку рани і процедуру повторювали в тому ж порядку. Кількість замірів залежала від площі опікової рани та клінічної картини. Цифрові показники вимірювань і графічне зображення ЛДФ-грами зберігалося в пам'яті комп'ютера.

Для забезпечення рівних умов дослідження у всіх групах спостережуваних пацієнтів проводили визначення середніх значень показників мікроциркуляції в різних ділянках опікової травми. Після об'єктивної оцінки в проекції ураження проводили визначення кровотоку по центру та периферії ран.

У результаті проведених обстежень з'ясувалося, що показники мікроциркуляції на клінічно подібних ділянках практично не відрізнялися один від одного. На підставі цього вирішено вибір ділянок опікової поверхні для ЛДФ-дослідження здійснювати, орієнтуючись на клінічну картину. Важливо, що ЛДФ-дослідження безболісне і не потребує для виконання багато часу, що дозволяє проводити його за будь-якої площі опікових ран.

В ході спостереження при виявленні показників флоуметрії нижче 1 ПФ ОД ділянку пошкодження шкіри розцінювали як глибоке опікове ураження (опік ІІІ Б ступеня). У випадку реєстрації показників кровотоку вище 1,5 ПФ ОД, залежно від величини, ділянку травми розцінювали як поверхневий опік (I, II, II А ступенів).
Результати та їх обговорення. Аналізуючи динаміку досліджень кровотоку за допомогою ЛДФ на опікових ділянках I, II ступенів було встановлено, що у групі, у якій використовували в якості місцевого лікувального засобу марлеві пов'язки з антисептиками (бетадин, діоксидин, декасан) на 5 добу досліджень показники ЛДФ статистично достовірно зменшшилися на $-22,2 \%(\mathrm{p}<0,001)$ порівняно 31 добою, а до 9 доби показники були вже на 44,5\% (p<0,001) меншими. При цьому на 13-14 доби відбувалося падіння показників ЛДФ від початкових значень до норми.

У свою чергу, на тлі лікування опіків з використанням гідрогелевих монопов'язок рівень ЛДФ статистично достовірно швидше зменшувався, в порівнянні з лікуванням під пов' язками з антисептиками. Вже на 5 добу, порівняно із першою, досліджуваний показник зменшувався на 26,9\% ( $<<0,001)$, а на 9 добу - на 53,7\% ( $<<0,001)$. Слід зазначити, що величина досліджуваного показника вже на 11 добу була в межах норми (рис. 1).

Застосування з метою лікування комбінованих гідрогелевих пов'язок та сорбуючих засобів на опікових поверхнях I, П ступенів приводило до швидкої нормалізації показників ЛДФ, i, відповідно, швидшого загоювання опікових ран. На 5 добу, порівняно із першою, показники статистично достовірно зменшпилися на 33,3\% (p<0,001), на 9 добу - на 67,7\% ( $<<0,001)$, наближаючись до норми. В останній термін спостереження показники ЛДФ виявилися істотно

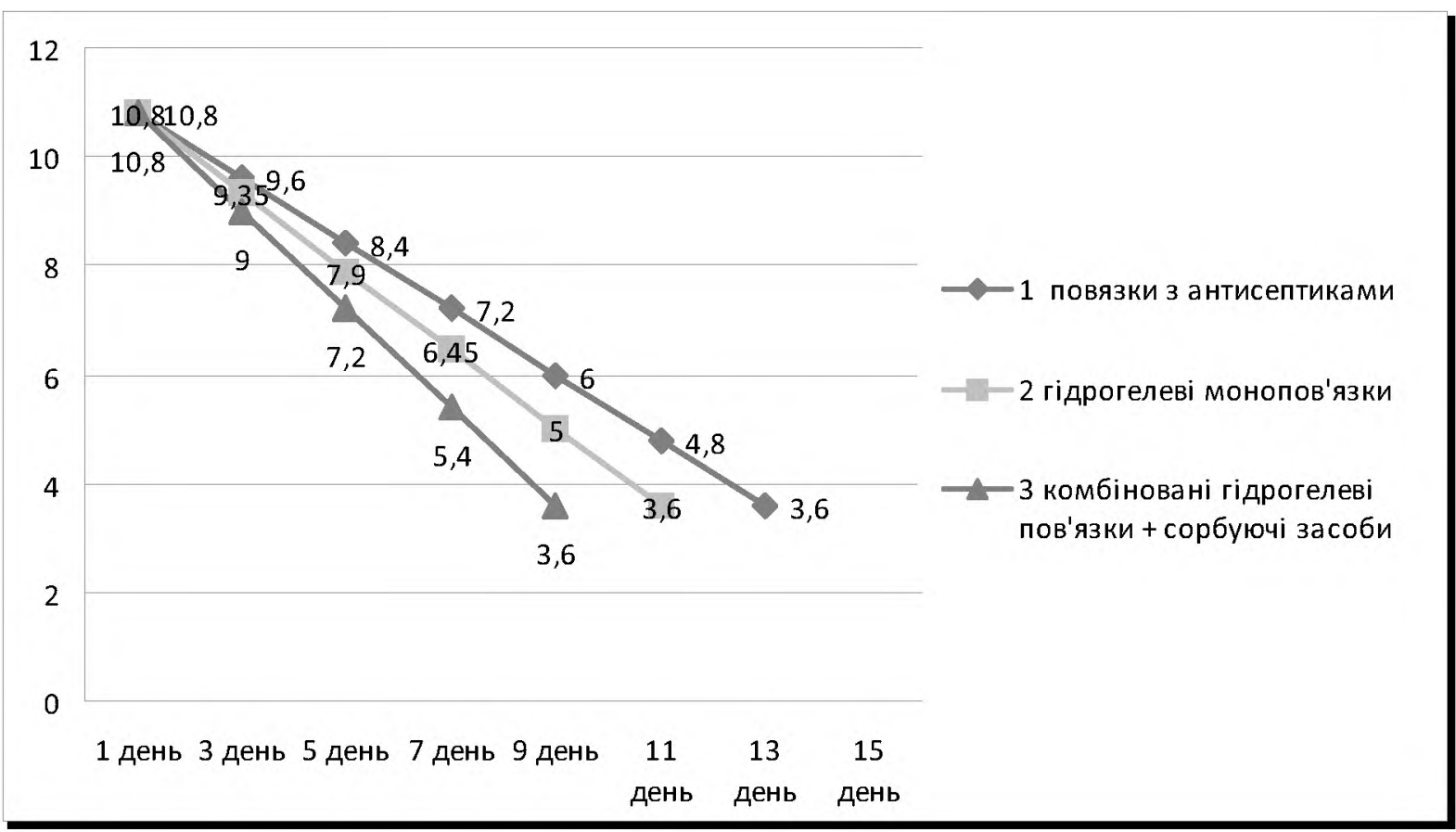

Puc. I. Динаміка показників ЛДФ у хворих з опіками I, П ступенів при місцевому застосуванні антисептиків, гідрогелевих монопов'язок і комбінованих гідрогелевих та сорбуючих засобів. 
нижчими, ніж на 5 добу спостереження (на $50 \%$, $\mathrm{p}<0,001$ ).

Показники динаміки ЛДФ статистично достовірно різнилися залежно від методу лікування на поверхнях iз I, I ступенями опіків (табл. 1). Так, після використання гідрогелевих монопов'язок вже на 5 добу відмічалося статистично достовірно швиидше спадан- ня показників ЛДФ в сторону нормалізації, порівняно з 1 групою, у якій застосовували традиційне лікування (на 5,95 \%, p<0,001). В 3 групі хворих, у якій застосовували комбіновані гідрогелеві пов'язки та сорбуючі засоби, до 5 доби нормалізація показників відбувалася ше швидше, порівняно з 1 групою контролю (на $14,3 \%, \mathrm{p}<0,001$ ).

Таблиця 1. Показники ЛДФ на ділянках опіків I, II ступенів на 1, 3, 5, 7, 9, 11, 13, 15 доби лікування (M \pm m)

\begin{tabular}{|l|c|c|c|c|}
\hline \multicolumn{1}{|c|}{ Показник } & $\begin{array}{c}\text { Традиційне } \\
\text { лікування, } \\
\text { група }(\mathrm{n}=17)\end{array}$ & $\begin{array}{c}\text { Гідрогелеві } \\
\text { монопов язки, } \\
2 \text { група (n=52) }\end{array}$ & $\begin{array}{c}\text { Комбіовані гідрогелеві } \\
\text { пов язки та сорбуочі засоби, } \\
\text { 3 група (n=55) }\end{array}$ & $p$ \\
\hline ЛДФ ПФ ОД 1 доба & $10,8 \pm 0,9^{*}$ & $10,8 \pm 0,9^{*}$ & $10,8 \pm 0,4^{*}$ & $<0,001$ \\
\hline ЛДФ ПФ ОД 3 доба & $9,6 \pm 1,3^{*}$ & $9,35 \pm 0,2^{*}$ & $9 \pm 0,4^{*}$ & $<0,001$ \\
\hline ЛДФ ПФ ОД 5 доба & $8,4 \pm 1,1^{*}$ & $7,9 \pm 0,5^{*}$ & $7,2 \pm 0,3^{*}$ & $<0,001$ \\
\hline ЛДФ ПФ ОД 7 доба & $7,2 \pm 0,8^{*}$ & $6,45 \pm 0,3^{*}$ & $5,4 \pm 0,2^{*}$ & $<0,001$ \\
\hline ЛДФ ПФ ОД 9 доба & $6,0 \pm 0,9^{*}$ & $5,0 \pm 0,4^{*}$ & $3,6 \pm 0,3^{*}$ & $<0,001$ \\
\hline ЛДФ ПФ ОД 11 доба & $4,8 \pm 0,8^{*}$ & $3,6 \pm 0,3^{*}$ & - & $<0,001$ \\
\hline ЛДФ ПФ ОД 13 доба & $3,6 \pm 1,2^{*}$ & - & - & $<0,001$ \\
\hline
\end{tabular}

Примітки: Тут і в інших таблицях розділу:

1. " - достовірність відмінностей показників порівняно із контрольною групою $\left({ }^{*}-\mathrm{p}<0,05 ;{ }^{* * *}-\mathrm{p}<0,01 ;{ }^{* * * *}-\mathrm{p}<0,001\right)$;

2. p - достовірність відмінностей між групами хворих, які одержували різне лікування;

На тлі застосування гідрогелевих монопов'язок через 9 діб від початку лікування показники ЛДФ, порівняно із 1 контрольною группою, статистично достовірно зменшувалися (на 16,7\%, p<0,001). В 3 групі до 9 доби показники ще в більшій мірі різнилися, порівняно 1 групою (на 40,0 \%, p<0,001), і сягали норми. Нормалізація показників 2 групи відбувалася до 11 доби. На даний час, порівняно із 1 групою, показники ЛДФ були меншими на 25,0\%, p <0,001.

Таким чином, на обпечених ділянках I, II ступенів відбувається статистично достовірно швидша нормалізація показників ЛДФ при використанні гідрогелевих монопов' язок та комбінованих гідрогелевих та сорбуючих засобів, порівняно із 1 контрольною групою, у якій проводили місцеве лікування опікових поверхонь під пов' язками з антисептиками. Порівнюючи показники 2 i 3 груп між собою можна констатувати, що вже на 5 добу відмічається виражена статистично достовірна різниця показників ЛДФ з переважанням позитивної динаміки нормалізації в 3 групі.

Аналіз динаміки кровотоку за допомогою ЛДФ на ділянках із опіком III А ступеня показав (рис. 2), що у 1 групі, у якій використовували традищійне лікування, досліджуваний показник на 5 добу спостереження практично не змінився, порівняно із 1. На 7 добу, після проведеної некректомії, рівень показників ЛДФ збільшився на 48,65\% $(p<0,001)$. Проте надалі відмічався спад, і на 9 добу показники ЛДФ були лише на 9,5\% ( $<0,001)$ вищими, ніж на 1 добу. Згодом збільшення показників ЛДФ в даній групі було повільним. На 15 добу васкуляризація в даній групі була на $32,14 \%(\mathrm{p}<0,001)$ вищою, порівняно із 1 добою. Повне відновлення васкуляризації, за даними ЛДФ, відбувалося до 22 доби, коли показники збільшилися на 47,2\% (p<0,001) ібули на рівні норми. Водночас при проведенні раннього хірургічного лікування з використанням гідрогелевих монопов' язок у 2 групі, на 3 добу дані ЛДФ статистично достовірно зростали на 58,7\% ( $<<0,001)$, порівняно із 1 добою. Далі на 5 добу дещо знижувалися, перевищуючи показники 1 доби на $24,0 \%(\mathrm{p}<0,001)$, з наступним стабільним ростом. На 9 добу дані були на 34,5 \% (p<0,001) білышими, порівняно із 1 добою. При використанні цієїметодики лікування повне відновлення кровопостачання на ділянках ураження відбувалося до 15 доби, порівняно з першою показники ЛДФ зростали на 45,7 \% (p<0,001).

Застосування комбінованих гідрогелевих та сорбуючих засобів у третій групі хворих при опіках ІІІ А ст. приводило до відновлення показників ЛДФ, які на 5 добу, порівняно із першою, були вицими на $40,6 \%$ ( $<<0,001)$, на 9 добу зростали на 44,1\% ( $<<0,001)$, на 11 добу - на 45,7\% (p<0,001), сягаючи норми. Слід зазначити, що величина досліджуваного показника на 11 добу істотно перевищувала аналогічну на 5 - на $8,6 \%(\mathrm{p}<0,001)$. 


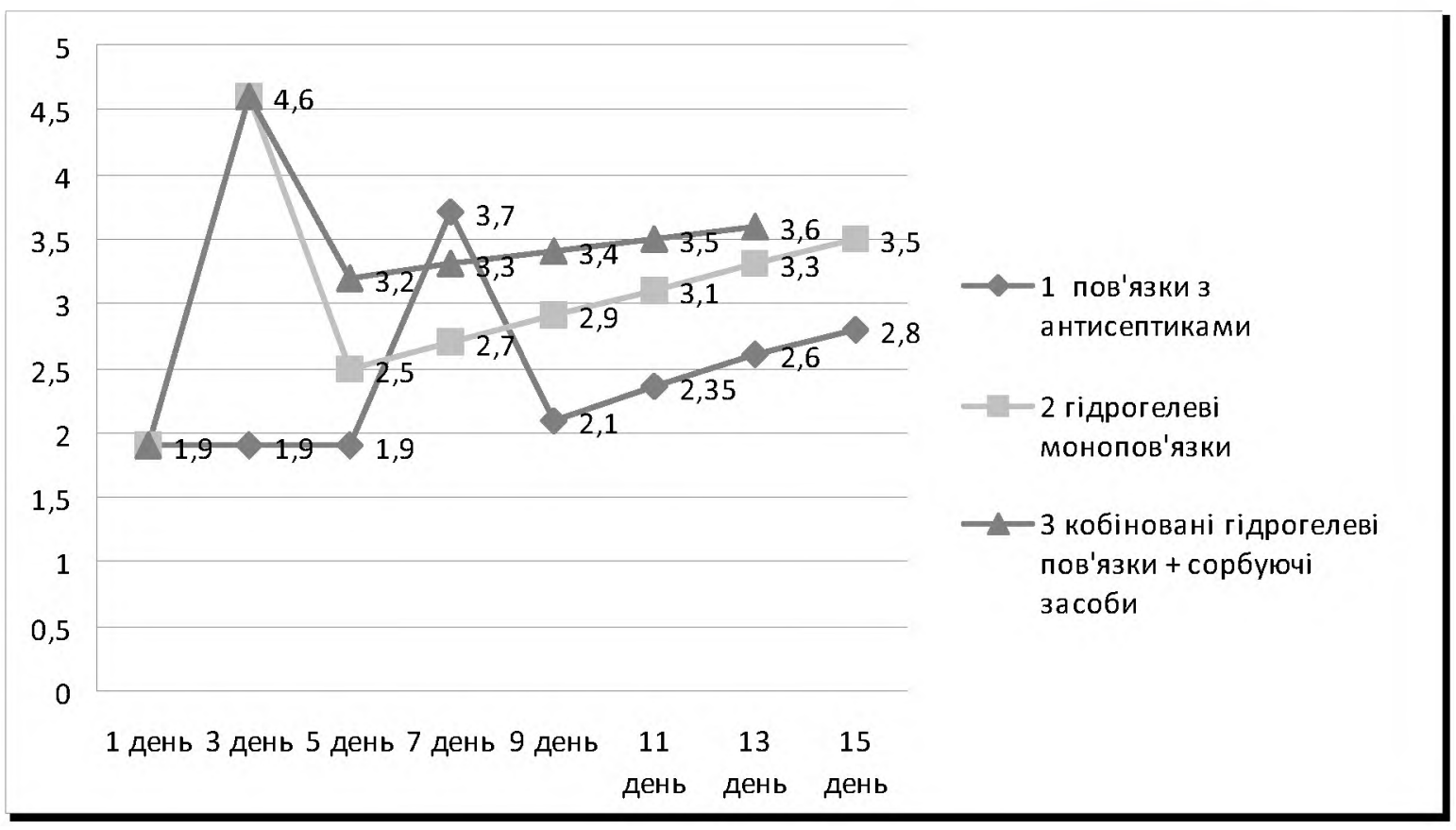

Puc. 2. Динаміка показників ЛДФ на обпечених ділянках III А ступеня при місцевому застосуванні антисептиків, гідрогелевих монопов'язок і комбінованих гідрогелевих та сорбуючих засобів.

У проекції опіків III А ступеня, для лікування яких використовували гідрогелеві монопов'язки, вже на 5 добу відмічалося статистично достовірне покращення результатів, порівняно із 1 групою, у якій були використані марлеві пов'язки з антисептиками (на $24,0 \%, \mathrm{p}<0,001)$. Через 9 днів показники ЛДФ зазна- вали ще білыш відчутних змін. Так, порівняно із контрольною 1 групою, ставали вищими на 27,6 \% $(\mathrm{p}<0,001)$. У свою чергу, повернення до норми відбувалося до 15 доби, на відміну від 1 групи (норма на 22 добу) і були статистично достовірно вищими на $20,0 \%(\mathrm{p}<0,001)$ (табл. 2$)$.

Таблиця 2. Показники ЛДФ в обпечених ділянках IIIА ступеня на 1, 3, 5, 7, 9, 11, 13, 15 доби лікування $(\mathrm{M} \perp \mathrm{m})$

\begin{tabular}{|c|c|c|c|c|}
\hline Показник & $\begin{array}{c}\text { Традиційне } \\
\text { лікувашня, } \\
1 \text { група }(\mathrm{n}=17)\end{array}$ & $\begin{array}{c}\text { Гідрогелеві } \\
\text { монопов'язки, } \\
2 \text { група }(\mathrm{n}=52)\end{array}$ & $\begin{array}{c}\text { Комбіновані гідрогелеві та } \\
\text { сорбуючі засоби, } \\
3 \text { група }(\mathrm{n}=55)\end{array}$ & $\mathrm{p}$ \\
\hline ЛДФ ПФ ОД 1 доба & $1,9 \pm 0,8$ & $1,9 \pm 0,8^{* *}$ & $1,9 \pm 0,8^{* * * *}$ & $<0,001$ \\
\hline ЛДФ ПФ ОД 3 доба & $1,8 \pm 0,6^{* *}$ & $4,6 \pm 0,6^{* * *}$ & $4,5 \pm 0,3^{* *}$ & $<0,001$ \\
\hline ЛДФ ПФ ОД 5 доба & $1,9 \pm 0,7^{* *}$ & $2,5 \pm 0,4^{* *}$ & $3,2 \pm 0,3^{\mathrm{km}}$ & $<0,001$ \\
\hline ЛДФ ПФ ОД 7 доба & $3,7 \pm 1,2^{* * * *}$ & $2,7 \pm 0,2^{s+3}$ & $3,3 \pm 0,2^{* * *}$ & $<0,001$ \\
\hline ЛДФ ПФ ОД 9 доба & $2,1 \pm 0,3^{* *}$ & $2,9 \pm 0,3^{* *}$ & $3,4 \pm 0,5^{* * *}$ & $<0,001$ \\
\hline ЛДФ ПФ ОД 11 доба & $2,35 \pm 0,3^{* * *}$ & $3,1 \pm 0,4^{* * 4}$ & $3,5 \pm 0,4^{* *}$ & $<0,001$ \\
\hline ЛДФ ПФ ОД 13 доба & $2,6 \pm 0,3^{* *}$ & $3,3 \pm 0,3^{* * *}$ & $3,6 \pm 0,3^{* *}$ & $<0,001$ \\
\hline ЛДФ ПФ ОД після 13 доби & $3,6 \pm 0,4^{* *}$ & $3,5 \pm 0,4^{* * *}$ & & $<0,001$ \\
\hline
\end{tabular}

На тлі комбінованого використання гідрогелевих пов'язок та сорбуючих засобів у пацієнтів при опіках III А ступеня, динаміка відновлення кровопостачання за даними ЛДФ та загоєння опікових поверхонь була найшвидшою. Порівняно із 1 групою, на 5 добу показники ЛДФ були вищими на 40,6 \% (p<0,001), 3 подальшим статистично достовірним ростом. Так, вже на 9 добу за даними досліджень відмічено на $38,2 \%(p<0,001)$ більші показники з подальшою тенденцією до покращення. На 13 добу дані ЛДФ 3 групи відповідали нормі, перевищуючи на 27,8 \% $(\mathrm{p}<0,001)$ показники 1 групи. 
При опіках III А ступеня відновлення кровопостачання та нормалізація показників ЛДФ відбувається статистично достовірно швидше в ділянках, в яких використовували гідрогелеві монопов'язки і комбіновані гідрогелеві та сорбуючі засоби, порівняно із 1 групою. Порівнюючи показники 2 i 3 груп між собою можна констатувати, що при опіках III А ступеня вже на 7 добу відмічається виражена статистично достовірна різниця показників ЛДФ між даними групами, з переважанням позитивної динаміки нормалізації в 3 групі.
Як видно з рисунка 3, у контрольній 1 групі показники ЛДФ до 5-6 доби (проведення некректомії) залишалися на одному рівні і практично не змінювалися. Після проведеної некректомії відмічалося підняття показників до 7 доби на $78 \%(\mathrm{p}<0,01)$, порівняно 3 1 добою, з наступним падінням. На 9 добу показники ЛДФ були на $38,9 \%(\mathrm{p}<0,01)$ вищими, порівняно 3 показниками на першу добу. Згодом відмічали статистично достовірне збільшення показників з нормалізацісю ЛДФ до 13 доби (на 66,7\% (p<0,01) вищі, порівняно 31 добою).

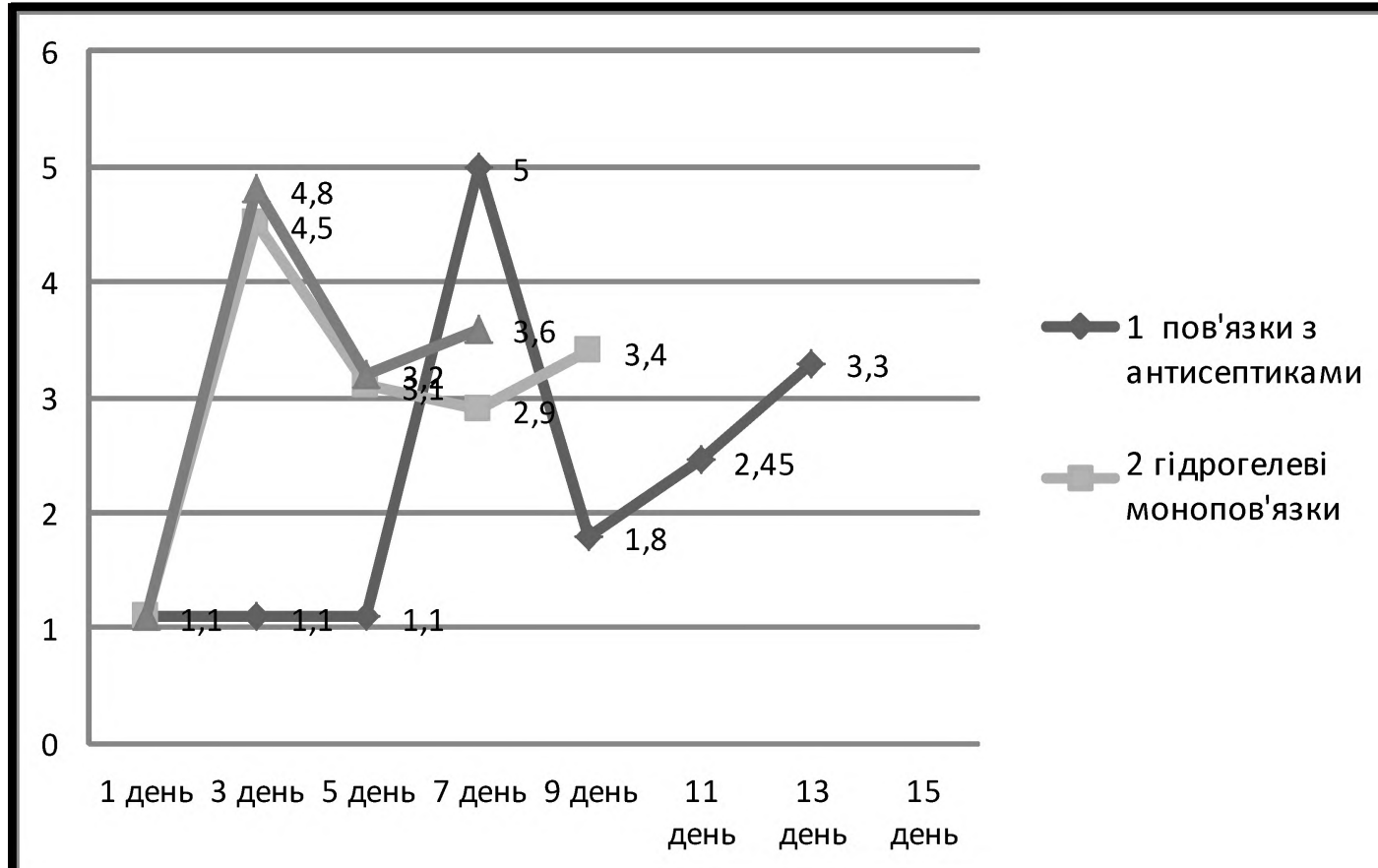

Puc. 3. Динаміка показників ЛДФ на ділянках з опіками III В ступеня при місцевому застосуванні антисептиків, гідрогелевих монопов' язок та комбінованих гідрогелевих та сорбуючих засобів.

На тлі використання гідрогелевих монопов'язок при проведенні раннього хірургічного лікування спостерігався ріст показників ЛДФ одразу після проведення некректомії на 75,6\% $\%$ p<0,01) порівняно 31 добою (3 доба). Проте надалі відмічалося істотне зниження досліджуваного показника, яке, порівняно із першою, на 5 добу, було більшим на 65,6\% (p<0,001), а на 7 добу зростало на $62,0 \%(\mathrm{p}<0,001)$. У подальшому дані ЛДФ стабільно росли і на 9 добу були на $67,6 \%(p<0,001)$ статистично достовірно більшими, ніж на 1 добу спостереження, і сягали норми. Привертає увагу той факт, що величини також виявилися достовірно більшими, порівняно із 5 добою спостереження (на 5,9\%, $<<0,001$ ).

В умовах застосування комбінованих гідрогелевих та сорбуючих засобів показники ЛДФ на 3 добу спостереження, після проведеної некректомії, порівняно iз першою зростали на 76,6\% $(\mathrm{p}<0,001)$. Подальше падіння показників було нетривалим, на 5 добу дані були вищими, порівняно 3 1, на 65,6\%, (p<0,001), а вже на 7 добу статистично достовірно зросли як стосовно першої, так і п'ятої діб (відповідно на 69,5\%, $\mathrm{p}<0,001$ i на $11,1 \%, \mathrm{p}<0,01)$ з поверненням до норми (табл. 3).

При проведенні порівняльної характеристики методів лікування виявили істотне зростання в 2 і 3 дослідних групах, порівняно із 1 контрольною, показників ЛДФ в ранні терміни, одразу після проведення ранньої некректомії (3 доба). Так, через 3 доби, порівняно з групою традиційного лікування, даний показник збільшився на 75,6\% (p<0,001) в 2 групі, та на 76,6\% (p<0,001) в 3 групі. Слід зауважити, що надалі відмічалося падіння показників в 2 та 3 групах і вже на 5 добу цифри були на 65,6\% $\%$ (p<0,001) 


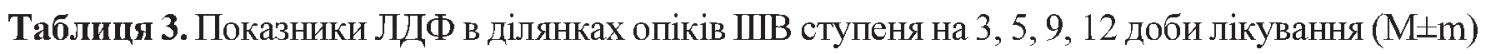

\begin{tabular}{|c|c|c|c|c|}
\hline Показник & $\begin{array}{c}\text { Традиційне лікування, } \\
1 \text { група (n=17) }\end{array}$ & $\begin{array}{c}\text { Гідрогелеві } \\
\text { монопов' язки, } \\
2 \text { група (n=52) }\end{array}$ & $\begin{array}{c}\text { Комбіовані гідрогелеві } \\
\text { та сорбуючі засоби } \\
3 \text { група }(\mathrm{n}=55)\end{array}$ & $\mathrm{p}$ \\
\hline ЛДФ ПФ ОД 1 доба & $1,1 \pm 0,5^{* * *}$ & $1,1 \pm 0,3^{* * *}$ & $1,1 \pm 0,5^{* * *}$ & $<0,001$ \\
\hline ЛДФ ПФ ОД 3 доба & $1,1 \pm 0,5^{* *}$ & $4,5 \pm 0,6^{* *}$ & $4,9 \pm 0,2^{* *}$ & $<0,001$ \\
\hline ЛДФ ПФ ОД 5 доба & $1,1 \pm 0,5^{* * * *}$ & $3,1 \pm 0,3^{* * * *}$ & $3,2 \pm 0,3^{*, * 17}$ & $<0,001$ \\
\hline ЛДФ ПФ ОД 7 доба & $5,0 \pm 0,6^{* *}$ & $2,9 \pm 0,4$ & $3,6 \pm 0,4^{*}$ & $<0,001$ \\
\hline ЛДФ ПФ ОД 9 доба & $1,8 \pm 0,1^{*}$ & $3,4 \pm 0,5^{* *}$ & - & $<0,001$ \\
\hline ЛДФ ПФ ОД 11 доба & $2,45 \pm 0,3^{*}$ & - & - & $<0,001$ \\
\hline ЛДФ ПФ ОД 13 доба & $3,3 \pm 0,6^{* * *}$ & - & - & $<0,001$ \\
\hline
\end{tabular}

більшими в 2 і 3 групах, порівняно з 1 . На 7 добу показники ЛДФ 1 групи перевищували дані 2 та 3 груп на $42,0 \%(\mathrm{p}<0,001)$ та $28,0 \%(\mathrm{p}<0,001)$ відповідно. Це пов'язано з проведенням пізньої некректомії напередодні та не відповідає нормі. Хоча вже в цей період (7 доба) в 3 групі показники ЛДФ піднялися близько до нормальних величин. На 9 добу за даними ЛДФ показники 2 групи також відновилися до норми і в порівнянні з 1 групою були на 47,0 \% ( $<<0,001)$ вищими. В 1 групі нормалізація васкуляризації тривала до 13 доби.

Висновки. 1.У спостережуваних групах пацієнтів, що підлягали ранній некректомії з використанням гідрогелевих засобів (2-3 група) найбілыш стрімке відновлення показників доплерівської флоуметрії виявлено в ділянках опіків IIIB ступеня. Застосування вищеописаних засобів вже на 3 добу лікування забезпечувало статистично достовірно швидше відновлення показників кровопостачання 3 подалышим ростом, порівняно із 1 групою, у якій проводилось лікування опікових поверхонь під пов'язками 3 антисептиками. Порівнюючи показники 2 і 3 груп між собою слід зазначити, що на ділянках, на яких застосовували комбіновані гідрогелеві та сорбуючі засоби, порівняно з використанням гідрогелевих монопов'язок, була виражена статистично достовірна різниця показників ЛДФ між даними групами 3 переважанням позитивної динаміки нормалізації в 3 групі.

2. У групі хворих, у якій застосовували традиційні методики з метою місцевого лікування (вологовисихаючі пов'язки з антисептиками) та проводилась відтермінована некректомія після 6 доби, повна епітелізація ран та відновлення нормальних показників кровопостачання за даними ЛДФ при поверхневих опіках I, II ступенів наставала, в середньому, на 1314 добу, на ділянках з опіками ПІІ А ступеня - на 23 добу.
3. У групі хворих, в якій застосовували з метою місцевого лікування гідрогелеві монопов'язки та проводили ранню некректомію відновлення нормальних показників, за даними ЛДФ, при опіках I, I I ступенів відбувалося в середньому на 9-11 добу, на ділянках з III А ступенем опіків - 15-16 добу. Рани з опіками III В ступеня були готові до аутодермопластики в середньому до 8-9 доби після отриманої травми.

4. У групі хворих, в якій застосовували комбіновані гідрогелеві пов'язки та сорбуючі засоби і проводили ранню некректомію: при опіках I, П ступенів відновлення нормальних показників ЛДФ та повна епітелізація ран відбувалися в середньому на 8-9 добу. Загоєння ран із III А ступенем опіків тривало в середньому до 12-14 доби з відновленням показників ЛДФ до 3,5 ПФ ОД. На ділянках із ІІІ В ступенем опіків, де була проведена рання некректомія на 2 добу від моменту отримання термічної травми та підготовка ран до аутодермопластики 3 використанням комбінованих гідрогелевих пов'язок та сорбуючих засобів, відновлення задовільного кровопостачання тривало в середньому до 7-8 доби після отриманої травми.

5. На ділянках із опіками I, II ступенів відбувається статистично достовірно швидша нормалізація показників ЛДФ при використанні гідрогелевих монопов'язок та комбінованих гідрогелевих та сорбуючих засобів, порівняно із 1 контрольною групою, де для лікування використовували пов' язки з антисептиками. Порівнюючи 2 і 3 групи між собою можна констатувати, що вже на 5 добу відмічасться виражена статистично достовірна різниця показників ЛДФ з переважанням позитивної динаміки нормалізації в 3 групі.

При опіках III А ступеня відновлення кровопостачання та нормалізація показників ЛДФ відбувається статистично достовірно швидше на ділянках, де використовували з метою лікування гідрогелеві моно- 
пов' язки і комбіновані гідрогелеві та сорбуючі засоби, порівняно із 1 групою, де проводилось лікування опікових поверхонь під пов' язками з антисептиками. Порівнюючи показники 2 і 3 груп між собою можна констатувати, що при опіках ПІІ А ступеня, вже на

\section{Література}

1. Козинець Г. П. Опікова хвороба/ Г. П. Козинець, О. Н. Коваленко, С. В. Слесаренко // Мистецтво лікування. - 2006.№ 12.-С. 9-15.

2. Клинико-анатомическое обоснование диагностики и лечения ожоговой травмы : учеб. пособне / А. В. Колсанов, А. В. Толстов, А. А. Филимонов [и др.]. - Самара : СамГМУ, 2009.- $146 \mathrm{c}$.

3. Диагностика и лечение ожоговой травмы : монография / С. А. Усик, А. В. Толстов, У. С. Беслекоев [и др.].-- Самара : СамГМУ, 2008. $-106 \mathrm{c}$.

4. Козлов В. И. с соавт. «Биофизические принципы лазерной допплеровской флоуметрии» // Материалы второго всероссийского симпозиума по применению ЛДФ в медищинской практике. - Москва, 1998.

5. Корж Е. В. Состояние плода и новорожденного в условиях микроциркуляторных нарушений при поздних гестозах у матери : автореферат дис. канд. мед наук / Е. В. Корж, 2000 .

6. Yonov Y. Letal causes in burn patients over the age of sixty years in Bulgaria / Y. Yonov, N. Serdev, V. Vassilev // Ann. of Burns and Fire Dis. - 1998. - Vol. 11. №1.-P. 16-18.
7 добу відмічається виражена статистично достовірна різниця показників ЛДФ між даними групами 3 переважанням позитивної динаміки нормалізації в 3 групі.

7. Исследование колебаний микроциркуляции в системе кровотока / В. И. Козлов [с соавт.] // Материалы второго всероссийского симпозиума по применению ЛДФ в мед. практике.-Москва, 1998.

8. Лазерная допплеровская флоуметрия микроциркуляции крови : руковод. для врачей / под ред. А. И. Крупаткина, В. В. Сидорова. - М. : Медицина, 2005. - 256 c.

9. Holland A. J. Laser Doppler imaging predictionof burn wound outcome in children A. J. Holland, H. C. Martin, D. T. Cass //Burns. - 2002. - Vol. 28, № 1. - P. 11-17.

10. Laser Doppler imagingdetermines need for excision and grafting in advance of clinical judgment: a prospective blinded trial / J.C. Jeng, A. Bridgeman, L. Shivnan [et al.] // Burns. 2003. -Vol. 29, № 7.- P. 665-670.

11. Kloppenberg F. W. Perfusion of burn wounds assessed by laser doppler imaging is related to burn depth and healing time/ F. W. Kloppenberg, G. I. Beerthuizen, H. J. Duis // Burns. 2001. - Vol. 27, № 4. - P. $359-363$. 